\title{
A EUROPA E SUAS FRONTEIRAS, UMA QUESTÃO PROBLEMÁTICA ${ }^{1}$
}

\author{
Clarisse Didelon ${ }^{2}$ \\ Delphine Blanchard ${ }^{3}$
}

\section{Resumo}

O artigo aborda a questão das fronteiras no interior da União Europeia reconhecendo que se trata de uma questão ao mesmo tempo sensível e problemática: sensível porque ela está ligada a escolhas políticas importantes relacionadas à sociedade (livre comércio, livre circulação ou fechamento das fronteiras à migração); problemática porque duas tendências principais e contraditórias perpassam a política fronteiriça europeia - a abertura das fronteiras internas e o fechamento das fronteiras externas. Após indagarem quais são os impactos desta dupla política fronteiriça sobre o território europeu, o artigo trata dos limites da Europa; a questão da identidade e da percepção dos limites e das descontinuidades fronteiriças; a questão do alargamento da União Europeia e a política regional com ênfase para as regiões transfronteiriças; a construção do território europeu, a contradição entre a abertura de fronteiras internas (Espaço Schengen, 1991) e o fechamento das fronteiras externas e as consequências desta política, como o número crescente de mortes de migrantes que batem às suas portas.

Palavras-chave: Fronteiras Internas e Externas. Limites da Europa. Alargamento da União Europeia. Política Regional de Região Transfronteiriça

\begin{abstract}
The paper addresses the issue of borders within the European Union recognizing that this is an issue at the same time sensitive and problematic: sensitive because it is linked to important policy choices related to society (free trade, free movement or closing of borders to migration); problematic because two major and contradictory trends permeate the policy frontier in Europe - the opening of internal borders and the closure of external borders. After inquiring what are the impacts of this double border policy on European territory, the paper discusses the limits of Europe; the question of identity and perception of limits and borders' discontinuities; the issue of EU enlargement and regional policy with emphasis on border regions; the construction of European territory, the contradiction between the opening of internal borders (Schengen Espace, 1991) and the closure of external borders and the consequences of this policy, as the increasing number of deaths of migrants who knock at their doors.

Keywords: Internal and External Borders. Borders of Europe. European Union Enlargement. Regional Policy for Border Regions.
\end{abstract}

\section{INTRODUÇÃO: POR QUE A QUESTÃo DAS FRONTEIRAS É IMPORTANTE}

A questão das fronteiras no interior da União Europeia é uma questão ao mesmo tempo sensível e problemática. Sensível porque ela está ligada a escolhas políticas importantes relacionadas à sociedade (livre comércio, livre circulação ou fechamento das

\footnotetext{
${ }^{1}$ Tradução de Aldomar A. Rückert e Camilo Carneiro Pereira Filho.

${ }^{2}$ Geógrafa. Doutora em Geografia pela Universidade Paris VII Denis Diderot. Co-autora com Claude Grasland e Yann Richard do "Atlas de l'Europe dans le monde". Docente na Universidade do Havre. Atua no Laboratório UMR IDEES, équipe CIRTAI - Centre interdisciplinaire de recherche sur les mobilités. http://www.cirtai.org/ Email: cdidelon@ yahoo.fr ${ }^{3}$ Geógrafa. Doutoranda em Geografia na Université du Havre, no Laboratório UMR IDEES, equipe CIRTAI - Centre interdisciplinaire de recherche sur les mobilités. http://www.cirtai.org/. Email: dede_the_best@hotmail.fr
} 
fronteiras à migração). Problemática porque duas tendências principais e contraditórias perpassam a política fronteiriça europeia: a abertura das fronteiras internas e o fechamento das fronteiras externas. Quais são os impactos desta dupla política fronteiriça sobre o território europeu?

\section{OS LIMITES DA EUROPA - UMA QUESTÃO SENSÍVEL}

A questão dos limites externos da Europa é uma questão sensível porque a confusão é grande entre o a) objeto geográfico impreciso, que é a Europa, e b) o objeto institucional de limites espaciais claramente definidos, que é a União Europeia. A questão dos limites da Europa coloca problemas porque ela levanta vários questionamentos sobre a identidade da Europa, isto é, sobre os fenômenos que poderiam defini-la. Ela tem igualmente uma forte dimensão política, quando a analisamos sob o ângulo do alargamento da União Europeia e mesmo uma dimensão operacional quando é considerada a política regional da União.

\subsection{A QUESTÃO DA IDENTIDADE E DA PERCEPÇÃO DOS LIMITES / LIMITES E DESCONTINUIDADES FRONTEIRIÇAS}

A Europa é um objeto geográfico impreciso, sendo uma herança da visão de mundo construída na Idade Média (Grataloup, 2008), o que coloca vários problemas quando se trata de defini-la. Porém, definir o que é a Europa não é uma questão trivial, visto que a mesma coloca-se com maior intensidade quando se considera o problema do alargamento da União Europeia. De fato, o Tratado de Roma e os textos oficiais de fundação da "Comunidade Econômica Europeia", depois "União Europeia", mantêm silêncio sobre a questão da definição espacial da Europa, enquanto que, ao mesmo tempo, afirma-se que pode candidatarse à adesão da União Europeia todo o país que fizer esta solicitação. Todavia, alguns trechos destes documentos trazem um esclarecimento sobre a definição da Europa. Essas definições não são espaciais, mas elas estipulam que a União Europeia está fundada sobre valores e que a União deveria acolher todos os países europeus que respeitam os valores da Europa, isto é, a dignidade humana, a liberdade, a democracia, a igualdade, o respeito à lei e aos direitos do homem. Além disso, o país deve ser "europeu", mas se os valores da Europa são definidos, os limites geográficos não o são. Não se pode nem mesmo considerar as notas de Euro difundidas pelas instituições europeias. (Figura 01). 
Figura 01. Nota de 20 Euros

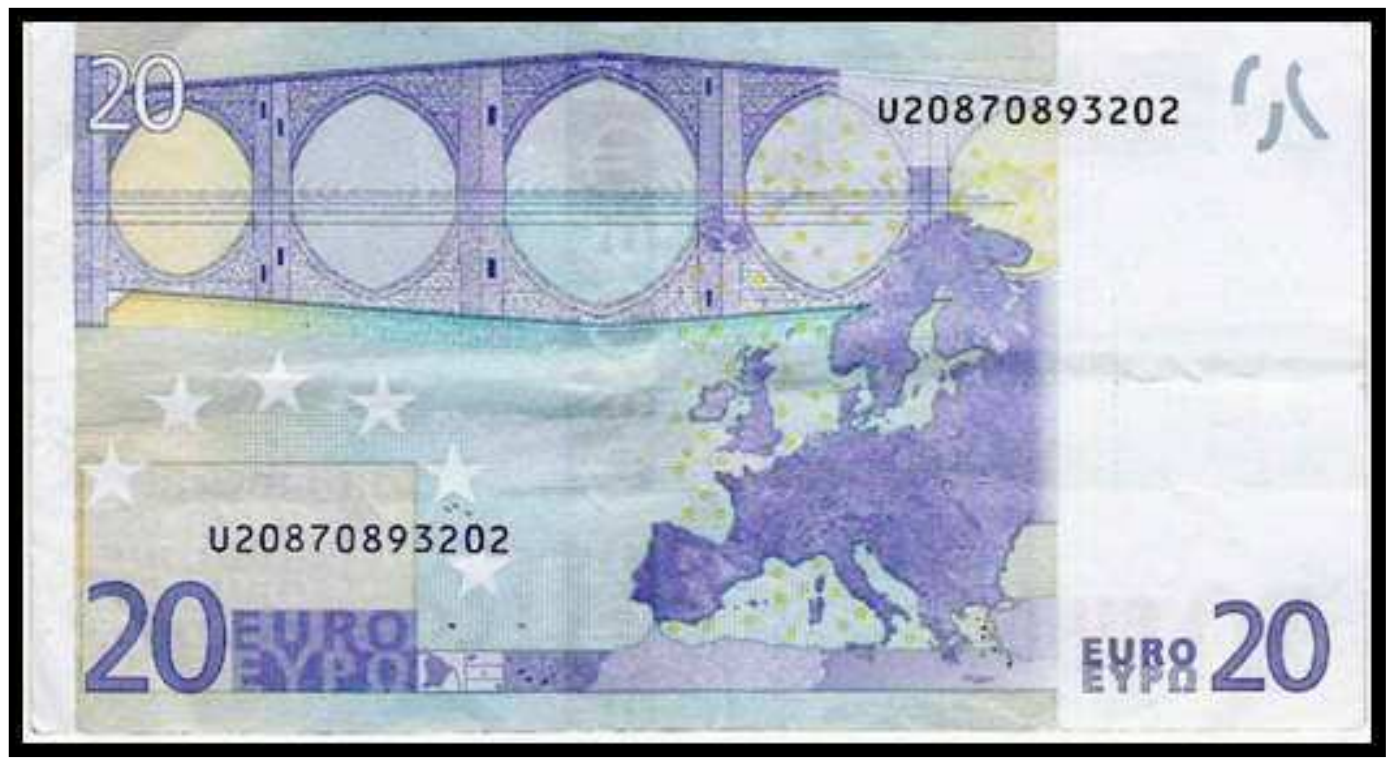

Fonte: http://www.wikipedia.fr

Figura 02. As instituições europeias e os países-membros

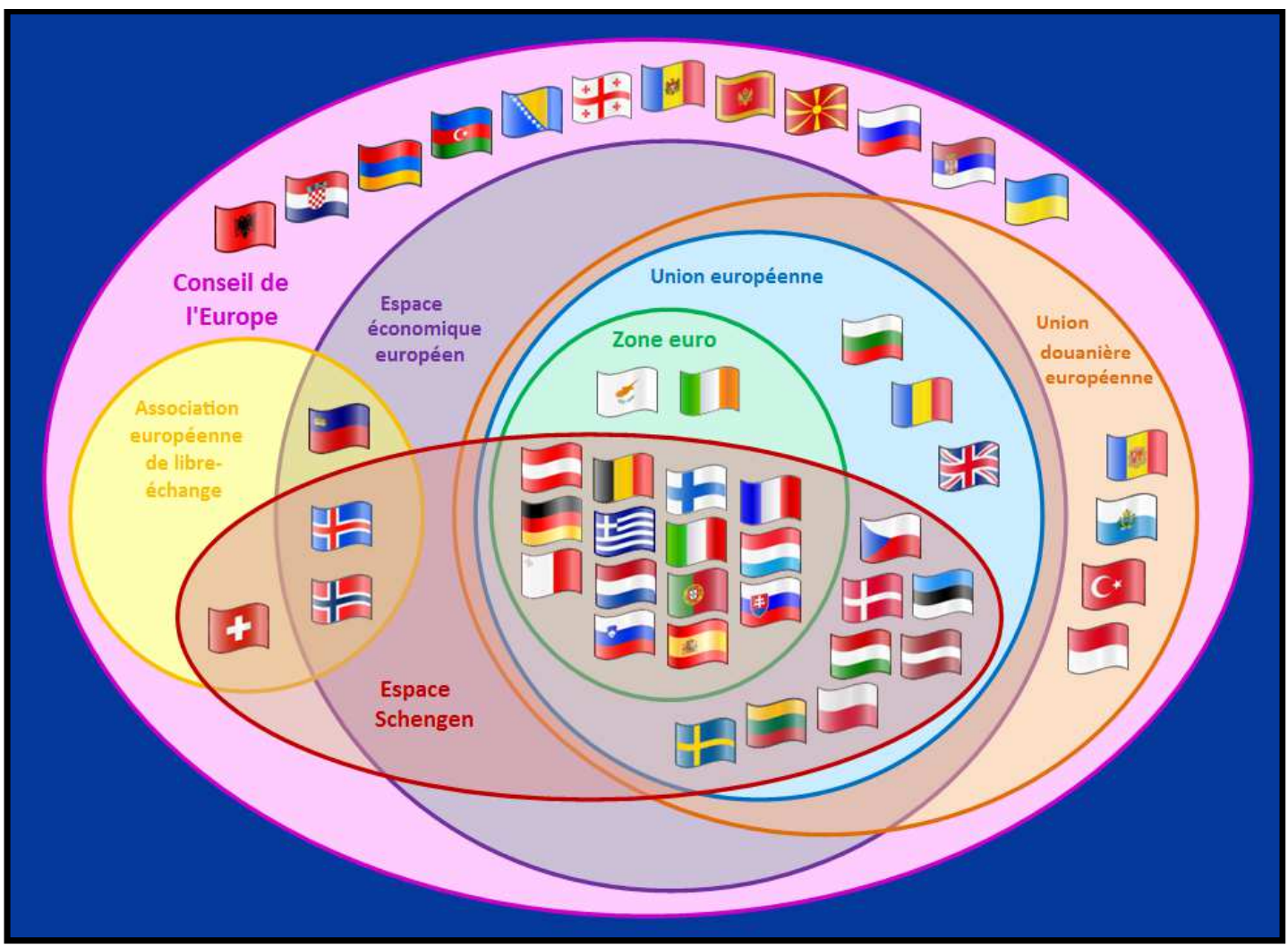

Fonte: http://www.wikipedia.fr 
Enfim, mesmo no interior das instituições europeias, os limites são móveis e imprecisos, uma vez que nem todos os países da Europa e nem mesmo alguns países da vizinhança estão engajados nos mesmos processos institucionais ou legais. Assim, há vários territórios institucionais nos quais as regras se aplicam ou não: nem todos os países da União Europeia fazem parte do Espaço Schengen ou da Zona Europa (a Grã-Bretanha, por exemplo), enquanto que países não-membros da União Europeia podem fazer parte da união aduaneira europeia (a Turquia) ${ }^{4}$, do Espaço Schengen e do espaço econômico europeu (Noruega).

Os mapas antigos não são de muita utilidade para definir o que é a Europa. Acontecese frequentemente (mas não sempre) que o Norte da África não seja informado nos mapas, os limites ao Leste são problemáticos, em particular o caso da Rússia e da Turquia, país que foi a sede do Império Otomano, que chegou a incluir, quando em sua extensão máxima, vários países europeus (Figura 03).

Figura 03. Mapa antigo da Europa em torno de 1560

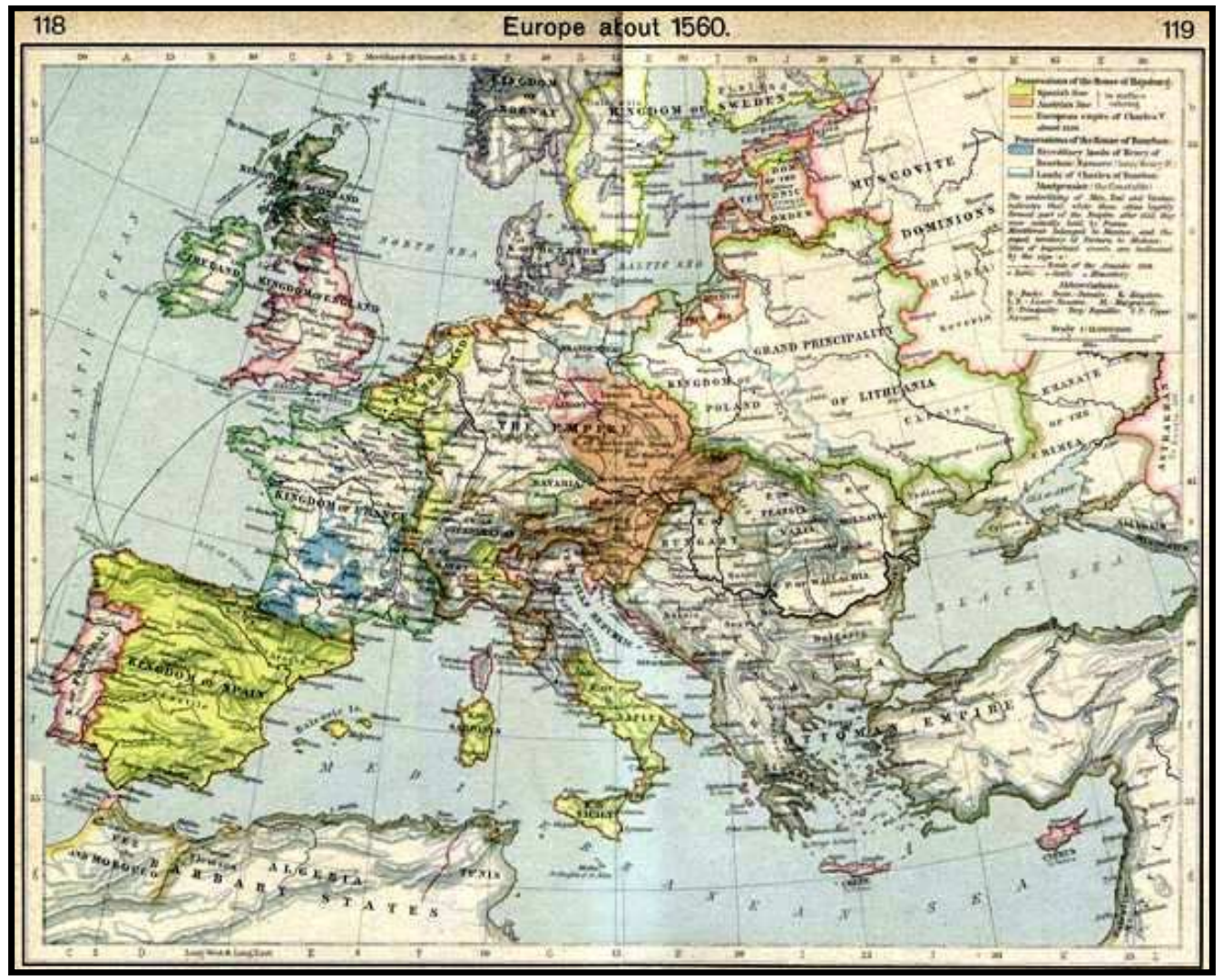

Fonte: http://lesreformes.over-blog.com/

\footnotetext{
${ }^{4}$ A Turquia solicitou, em 1959, o estatuto de membro associado da então Comunidade Econômica Europeia (CEE). Em 1973, o Acordo de Ancara (1963) e os respectivos protocolos adicionais permitem à Turquia poder integrar a União Aduaneira. O acordo sobre a União Aduaneira, concluído pelo Conselho de Associação Turquia-UE, entrou em vigor em $1^{\circ}$ de janeiro de 1996 (http://www.eurocid.pt) (NT).
} 
Também não se pode mais levar em conta as fronteiras ditas "naturais" que não existem, a não ser pelo fato de que elas foram escolhidas e institucionalizadas. O exemplo mais impressionante é dos Montes Urais, que são apresentados na maioria dos dicionários como sendo a fronteira oriental da Europa. De fato, esta fronteira convencional da Europa, frequentemente considerada como "natural", é uma construção geopolítica relativamente recente. Este limite foi estabelecido por Vasily Tatischev, o geógrafo do imperador russo Pedro, o Grande. Em 1730, ele sugeriu que a montanha e o Rio Ural eram o limite oriental do continente europeu. Esse limite foi estabelecido por razões puramente políticas: Pedro, o Grande acabava de fundar São Petesburgo e queria desenvolver as relações da Rússia com os países europeus e definir o pertencimento da Rússia a esse espaço. O que aconteceu para que esse limite tenha tido tão grande aceitação? É que Denis Diderot, o enciclopedista francês, era ligado à Catarina da Rússia. Assim, quando fez a enciclopédia ${ }^{5}$, ele retomou a definição do geógrafo russo. A enciclopédia conheceu uma grande difusão e foi nessa época que começaram a ocorrer os primeiros ensinamentos de Geografia. Depois de gerações, a Europa, o continente "Europa", é definida nos dicionários como se estendendo do Oceano Atlântico até os Urais. Essa fundação política da fronteira "natural" da União é hoje esquecida, e esse limite é apresentado como totalmente legítimo (não polêmico), o que não tem nenhum sentido, já que os Urais jamais formaram uma fronteira com quem quer que seja.

Alguns pesquisadores, em particular geógrafos, têm se debruçado sobre a questão dos limites da Europa e optaram por defini-la utilizando um sistema de gradientes que descrevem fenômenos considerados como fundadores da civilização ou da cultura europeia. Pode-se citar em particular Jaques Lévy (1997), que determinou duas grandes famílias de fenômenos que explicam, segundo ele, uma parte da identidade europeia. Primeiramente, a configuração física da Europa fez dela um abrigo contra as invasões que marcaram sua história, notadamente as das populações nômades. Sua forma de península no fim do continente euroasiático constituiu um tipo de gargalo de estrangulamento, no qual os invasores não se aventuravam. Além disso, as invasões podiam vir apenas de um lado. E também, e sobretudo, a densidade da ocupação rural e da estruturação social do espaço que se desenvolvia (redes de povoados amigos; vínculos entre os povoados) freou o avanço dos nômades que deveriam combater numerosos grupos humanos que tinham a vantagem de conhecimento prévio do

\footnotetext{
${ }^{5}$ A prima do escritor e filósofo Denis Diderot (Langres, 5 de outubro de 1713 - Paris, 31 de julho de 1784) é a edição da Encyclopédie (1750-1772), onde reportou todo o conhecimento que a humanidade havia produzido até sua época. Demorou 21 anos para ser editada, e é composta por 28 volumes. Mesmo que na época o número de pessoas que sabia ler era pouco, ela foi vendida com sucesso (http://pt.wikipedia.org/wiki/Denis_Diderot) (NT).
} 
terreno. Graças a essa configuração de abrigo é que começaram a existir, a oeste da Europa, formas de estados estáveis que interagiam entre si. Em segundo lugar, e isso constitui uma herança cultural, um certo número de textos, de concepções e de formas de ver o mundo que existiam antes da invenção da Europa desempenha um papel em sua identidade. J. Lévy identifica três grandes influências: a) o Império Romano como modelo de potência organizada e estável e cuja herança encontra-se nas instituições, as leis; b) o Cristianismo, que se difundiu no espaço da conquista romana; c) a herança grega, que constitui um tipo de disciplina do espírito, um método de pensar que tende a colocar o homem no centro da reflexão. A partir destes três tipos de influência, J. Levy descreve os núcleos da "Europeidade", em função do nível de influência dos elementos citados anteriormente. O núcleo da Europa, na qual a identidade europeia seria forte e inegável, seria, portanto, fácil de identificar. Por outro lado, seus limites não são definidos: é um espaço com limites imprecisos em forma de gradientes (Figura 04).

Figura 04. Gradientes de "Europeidade", segundo a análise feita por J. Lévy.

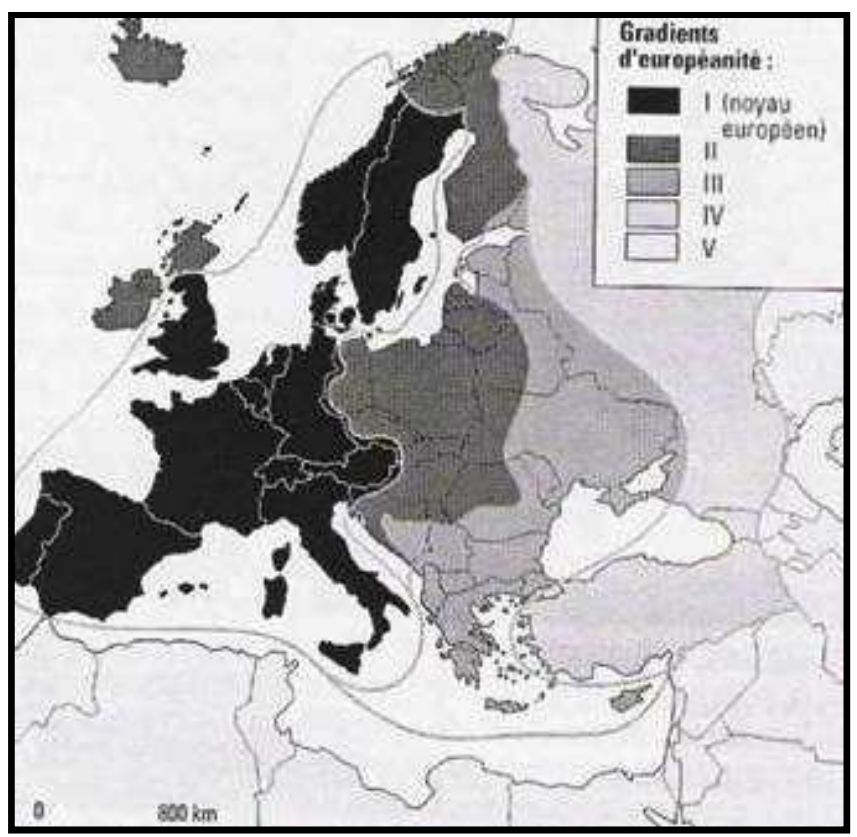

Fonte: J. Lévy, l’Europe, une géographie. 1997

É essa tendência que se encontra quando se estudam as representações mentais da Europa entre populações europeias e mesmo em países situados fora da União (ver os

\footnotetext{
${ }^{6}$ No original Européanité. O núcleo da Europeidade na Figura 4 consta na cor mais escura (NT).
} 
resultados do projeto Eurobroadmap: www.eurobroadmap.eu ${ }^{7}$ ). Assim, o mapa seguinte (Figura 05) propõe os resultados de uma pesquisa (Didelon C. Grasland, 2005, Didelon, 2010) sobre a visão da Europa por parte de pesquisadores e executores da gestão do território europeu.

Figura 05. Visão da Europa por parte de pesquisadores e executores da gestão do território europeu

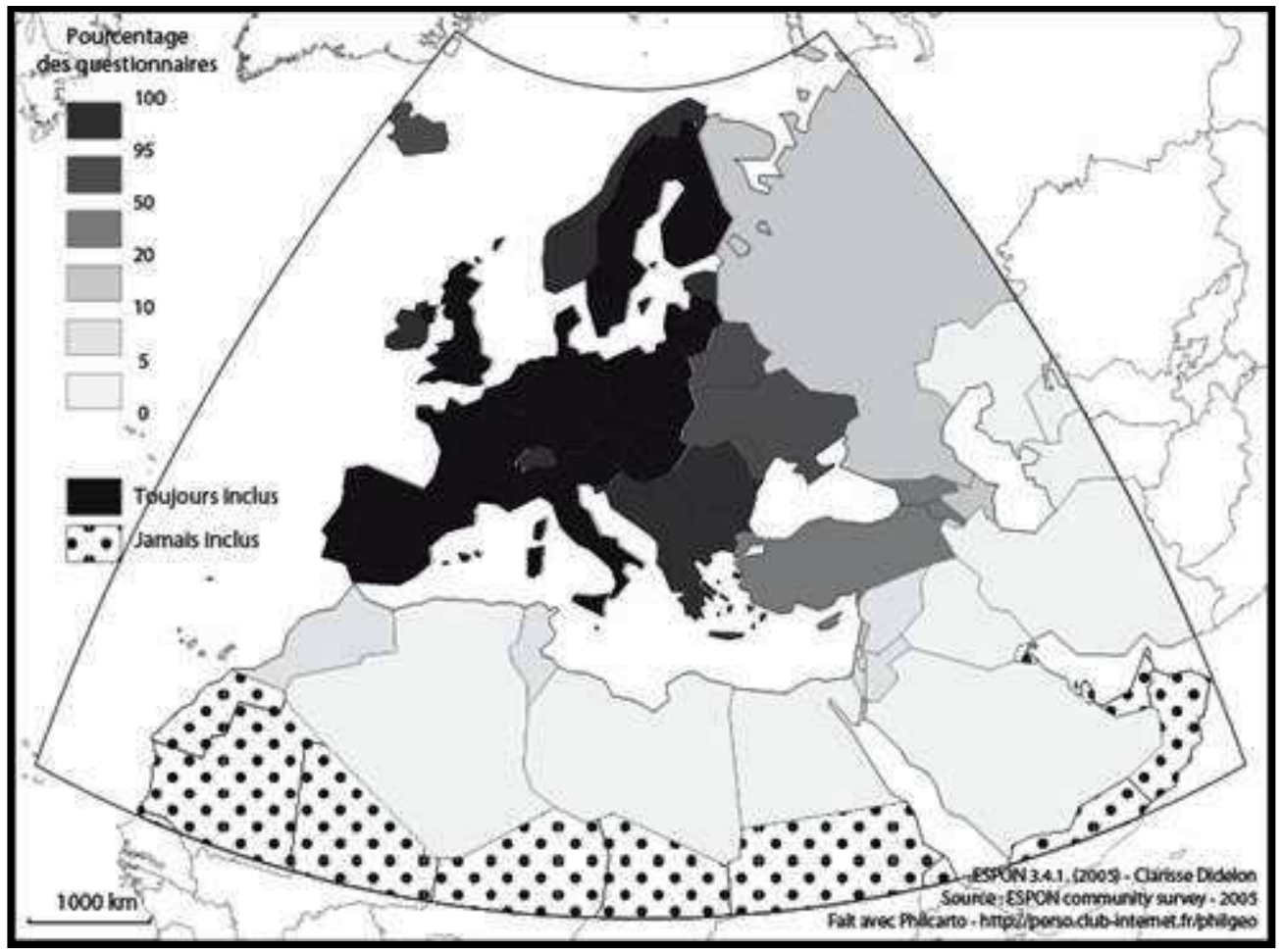

Fonte: Didelon C., Annales de géographies, 2010.

Nesta visão da Europa, dois grupos de países destacam-se do conjunto: aqueles que estão "sempre dentro", os quais nenhuma pessoa ao responder o questionário ousou colocar fora da Europa e os "sempre fora", aqueles cujo caráter não-europeu não deixa dúvidas para ninguém. Trata-se, no primeiro caso, dos países da União Europeia, de Gibraltar a ponta norte da Finlândia; dos seis países do Tratado de Roma; aqueles dos alargamentos sucessivos que aí constam, a não ser quando eles estão muito na periferia e/ou isolados (Chipre e Grécia,

\footnotetext{
${ }^{7}$ Neste projeto de pesquisa, as pessoas pesquisadas (estudantes universitários em vários países, dentre os quais o Brasil, nas cidades de São Paulo, Fortaleza, Manaus e Porto Alegre) foram convidadas a desenhar os limites da Europa, conforme a sua percepção pessoal, sobre um mapa contendo apenas os nomes dos países do continente euroasiático, o norte da África e do Oriente Médio (NT).
} 
Irlanda e Estônia). Dois não-membros são também cuidadosamente excluídos dos "sempre dentro da Europa": a Noruega e a Suíça. Há, portanto, um núcleo da Europa concentrado em torno da "banana azul"8. Os limites da União Europeia são, dessa forma, um elemento utilizado para definir a Europa sob o ponto de vista espacial. Esta escolha pode parecer surpreendente, já que o objetivo da pesquisa era definir "a Europa" para justamente determinar quais países poderiam eventualmente fazer parte da União Europeia no futuro. A escolha traduz igualmente o amálgama frequente entre a Europa e a Europa da União Europeia.

Quando se analisam os países que não pertencem a nenhum desses dois grupos, observa-se uma gradação bastante clara do Oeste para o Leste, em termos de grau de pertencimento à Europa. Essa gradação não para na fronteira da Federação da Rússia, que está geralmente menos integrada. Assinala-se a quase certeza a propósito da Europeidade dos Bálcãs, mas sua integração quase sistemática na Europa é talvez devido à sua situação intermediária entre o coração da Europa e a Grécia, que é membro da União... mesmo se esta é por vezes esquecida. Ao Sul, a ruptura constituída pelo Mediterrâneo é mais clara. Somente o Marrocos e a Tunísia são às vezes incluídos integralmente dentro da Europa. A Argélia, cuja região sul mergulha no Saara, é seguidamente excluída: somente sua parte norte está associada à Europa. Nesses países nem sempre incluídos, nem sempre excluídos, as frequências de inclusão assim como as motivações diferem muito. As situações são, portanto, bastante variáveis entre os países da Ásia Central, que constituem o "Far East" (extremo leste) da Europa, aqueles para os quais a "pena não hesita", e aqueles que, por contiguidade, ou por desafios funcionais (comerciais) (Rússia, Cáucaso, Turquia) ou estratégicos (laços históricos, migrações) (Marrocos, Tunísia, Oriente Médio) são por vezes incluídos, por vezes excluídos da Europa... Os traços a lápis dos pesquisadores sobre os mapas assim como os critérios invocados desenham, portanto, uma Europa bem definida pela cultura, por uma história comum (notadamente, a construção da União Europeia), por uma geografia fundada, por sua vez, sobre a ilusão continental e a proximidade geográfica, mas também pelos laços funcionais, principalmente comerciais, migratórios e energéticos. A Europa é, dessa forma, um objeto difícil de definir: se ela é percebida de maneira frequentemente consensual, seus

\footnotetext{
8 A "banana azul", também conhecida como "Hot Banana", "European Megalopolis" ou "European Backbone", é um corredor de urbanização no Oeste da Europa, com uma população aproximada de 110 milhões de pessoas. Ela se estende do Noroeste da Inglaterra, no Norte até Milão na Itália, ao Sul. O termo foi cunhado por um grupo de geógrafos em 1989, no grupo GIP Réclus, dirigido por Roger Brunet (NT).
} 
limites são particularmente fluidos. Esta situação gera problemas quando se visa ao alargamento do território europeu e à implantação de políticas regionais europeias.

\subsection{A QUESTÃO DO ALARGAMENTO E DA POLÍTICA REGIONAL}

A questão da gestão do território europeu na escala comunitária surgiu no início dos anos 1990, após o aumento do poder da política regional, que é, de qualquer forma, uma estratégia de desenvolvimento do território europeu. A gestão do território permanece uma prerrogativa dos estados da União que dispõem de fundos financeiros, os quais permitem apoiar ações e projetos. A distribuição dos fundos europeus se faz segundo certos princípios gerais. O princípio da coesão territorial, considerado como um complemento da noção de “coesão econômica e social”, corresponde a uma ideia de solidariedade que se exprime entre os territórios da União, através da aplicação da política regional. Seu objetivo é a diminuição das desigualdades, das diferenças e dos desequilíbrios entre os Estados e entre as regiões europeias, a fim de permitir a implantação do mercado interno e a melhoria da qualidade de vida dos cidadãos europeus. Um segundo princípio importante é o da equidade territorial, que é um dos princípios fundadores mais implícitos da construção europeia. Ele estipula que todos os cidadãos da União Europeia devem poder beneficiar-se de possibilidades comparáveis de acesso aos bens e serviços de interesse geral, quer de infraestrutura de transporte, acesso aos serviços sociais e de saúde à educação ou à cultura. Enfim, o princípio da convergência está baseado na ideia de que o respeito do princípio de coesão econômica, social e territorial na base da política regional europeia necessita da existência de uma convergência econômica entre as diferentes regiões. No quadro da política regional, o objetivo da convergência econômica designa a diminuição das desigualdades regionais, seja em termos de redução da dispersão dos níveis de riqueza por habitante, seja por uma recuperação dos países ou das regiões as mais desfavorecidas por meio de um crescimento mais importante. A fim de atribuir os fundos da política regional, foram criados critérios de eligibilidade. Para as regiões poderem se candidatar, devem dispor de $75 \%$ da média do PIB europeu.

Porém, o processo de algargamento conduz à integração de países mais pobres na União Europeia e, ao fim e ao cabo, a fronteira se desloca em direção ao Leste (Figura 6). De fato, se omitirmos a passagem da Europa dos 12 para a Europa dos 15, os alargamentos sucessivos são todos caracterizados por uma forte alta das desigualdades, por sua vez, entre os Estados e mesmo dentro desses Estados. A proporção da renda relativa entre a região mais 
rica e a mais pobre era de 1 para 5 na UE dos 15, em 2000. Ela passou de 1 para 9 na UE dos 25 e daí em diante de 1 para 13 na União Europeia dos 27. Os alargamentos de 2004 e de 2007 têm aumentado especialmente as disparidades de renda no interior da União Europeia. Em 2004, o PIB da zona integrada (10 países) não representava muito mais do que o dos Paises Baixos. Esse crescimento das disparidades manifestou-se pelo que é chamado de "o medo do encanador polonês" ${ }^{9}$. De fato, com a adesão dos países da Europa Central e Oriental à União Europeia, as desigualdades regionais europeias cresceram causando temor aos países mais ricos da União, em que um afluxo migratório de trabalhadores do Leste, cujos salários seriam mais baixos, entraria em concorrência com os operários e as empresas locais. Mas os fluxos migratórios tão temidos não aconteceram, inclusive nos países que haviam suprimido as medidas restritivas impostas à livre circulção dos trabalhadores. Em 2007, a Romênia e a Bulgária, por sua vez, entraram na União Europeia. Este sexto alargamento é, sem dúvida, um novo desafio para a União Europeia, que tem acolhido países cujo nível de vida é ainda mais baixo que o dos dez Estados que aderiram em 2004. É, portanto, igualmente um enorme desafio para a política regional, que deverá facilitar a recuperação econômica e social destes novos membros.

Assim, os temores nos antigos países-membros de não poder mais se beneficiar dos fundos da política regional foram grandes. De fato, pelo simples efeito mecânico, o alargamento reduziu de forma substancial a média comunitária do PIB por habitante. A fase da adesão de 2004 deslocou de uma só vez o centro de gravidade da política de coesão em direção ao Leste, porque a renda média da UE alargada diminuiu mecanicamente: 30 regiões beneficiárias dos fundos estruturais (cuja concessão é acionada quando o PIB por habitante em paridade do poder de compra é inferior a $75 \%$ da média europeia) perderam seus direitos aos auxílios europeus justamente quando elas sofriam de um atraso de desenvolvimento. Novos objetivos e condições de eligibilidade foram estabelecidos para aliviar o problema, mas a perspectiva de outros alargamentos e, portanto, do deslocamento da fronteira da União Europeia é um temor real entre as populações dos países mais ricos.

\footnotetext{
9 Quando da adesão da Polônia à União Europeia, houve receio de concorrência pela aceitação de salários mais baixos (dumping social) e, sobretudo, dos encanadores poloneses na França. É uma expressão francesa nitidamente histórica. Podese verificar detalhes em http://fr.wikipedia.org/wiki/Plombier_polonais ou em inglês em http://en.wikipedia.org/wiki/PolishPlumber (NT).
} 
Figura 06. As disparidades de desenvolvimento no espaço euromediterrâneo

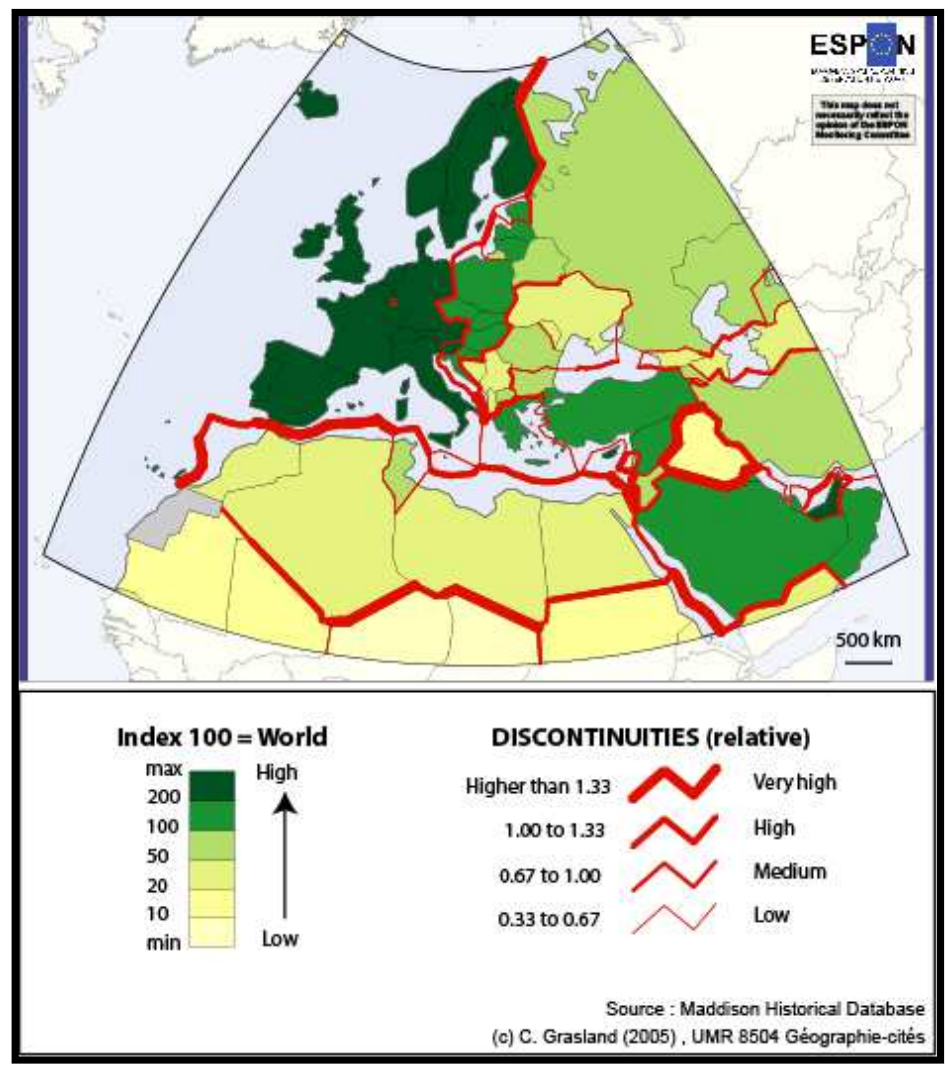

Fonte: Didelon C., Grasland C., 2005, ESPON 3.4.1. Europe in the world.

As fronteiras externas da UE, observadas do ponto de vista do território da União, apresentam igualmente problemas em termos de ordenamento do território europeu. Elas são realmente um tipo de "terminal", limite da ação no ordenamento do território europeu, mesmo quando são implementadas políticas de vizinhança. Essa situação é prejudicial para os paísesmembros da União que se encontram no limite do território europeu. Localizados em situação periférica, eles parecem ser o "ponto extremo", e os investimentos, principalmente em termos de infraestrutura, não são suficientes para melhorar a acessibilidade desses territórios. Além disso, ao mesmo tempo, esta situação coloca igualmente os países vizinhos da União Europeia em uma situação delicada, visto que esta escolha política prejudica o aprofundamento da parceria entre a UE e os seus vizinhos, criando neles um sentimento de abandono. Ela é igualmente suscetível de lhes afetar seu desenvolvimento, isolando esses países vizinhos com os quais eram mantidas anteriormnente relações mais fáceis, principalmente no que diz respeito aos antigos países do Leste Europeu. 


\section{AS FRONTEIRAS DA EUROPA: UMA ESCOLHA SOCIAL}

\subsection{A POLÍTICA IMPLEMENTADA}

O tema das fronteiras externas da União Europeia levanta inúmeras questões que a coloca frequentemente em situações contraditórias, em particular quando se trata da questão migratória. A contradição é muito forte nesse caso entre os ideais de livre comércio e de livre circulação que se aplicam no interior da União para bens e pessoas (e com o exterior da

Figura 07. Fronteira entre a Áustria e a Eslováquia

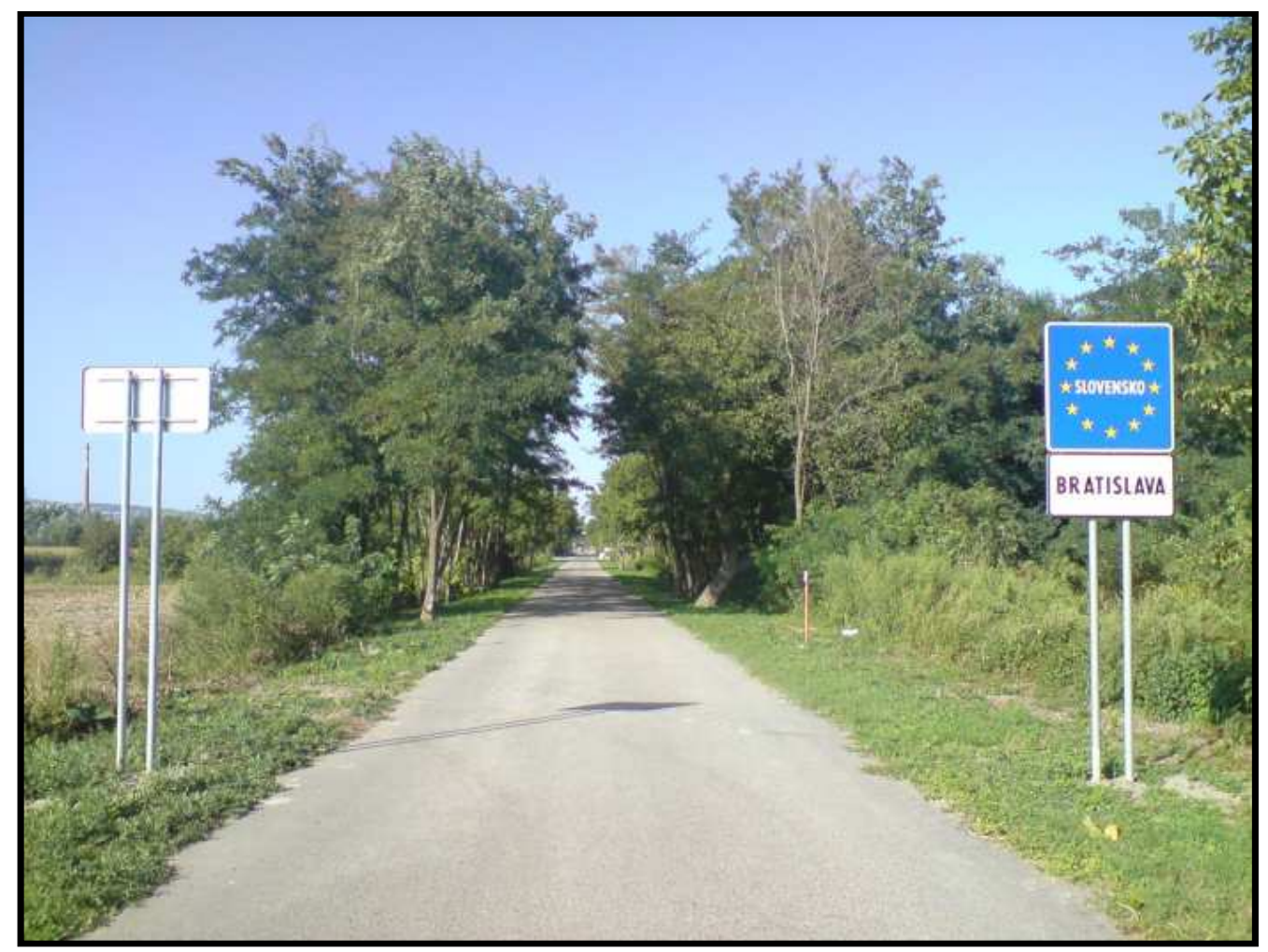

Fonte: http://wikipedia.org

União,em uma menor medida para os bens) e o fechamento das fronteiras exteriores da União às populações migrantes. As fronteiras internas da União não são mais visíveis, sendo integradas na paisagem como curiosidades (Figuras 7 e 8), enquanto as fronteiras exteriores se fecham. 
Figura 08. Fronteira entre a Bélgica e os Países Baixos

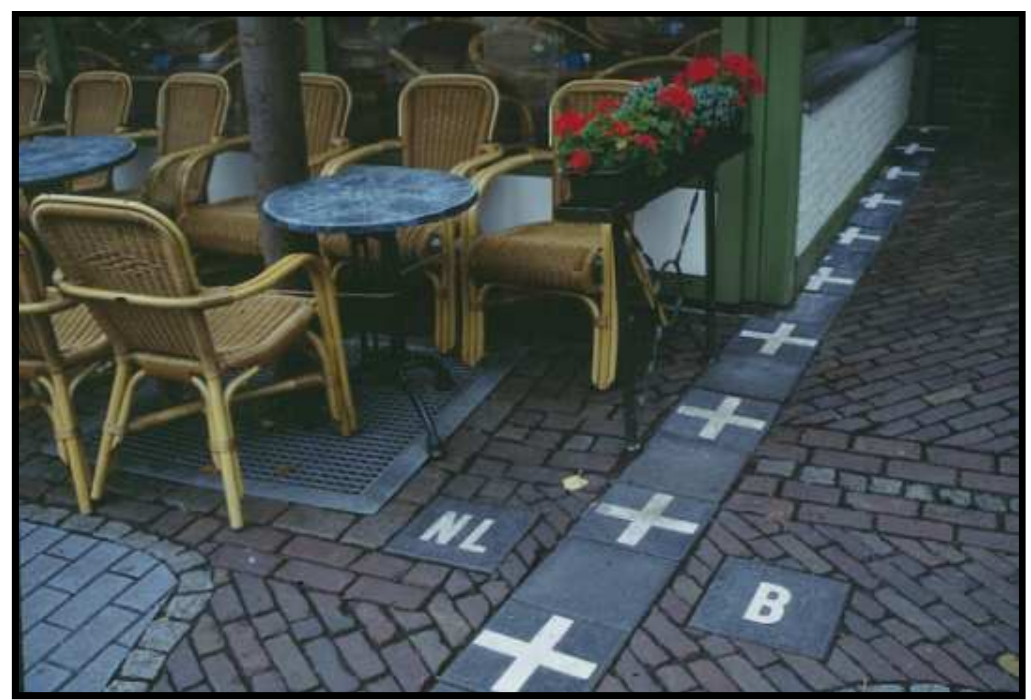

Fonte: http://gillesenlituanie.hautetfort.com/

A construção da União Europeia teve como efeito reforçar o desenvolvimento econômico do conjunto de países-membros, tornando um território rico, relativamente harmonioso social e economicamente. O contraste é grande entre a Europa e os territórios que a aderem em termos de nível econômico. Sua riqueza a faz atrativa, os migrantes e refugiados do mundo inteiro tentam penetrá-la. Todos os países da União Europeia tornaram-se países de imigração, ainda que alguns deles tenham sido países de migração antes de sua entrada no bloco: Itália, Espanha e Portugal em particular. Devido a essa atratividade, existe uma verdadeira pressão migratória sobre os países da União Europeia, mais importante que as crises econômicas ou políticas, e que surge nos territórios das proximidades do bloco. Esse tema de imigração veio rapidamente se impor como uma questão a se resolver na escala comunitária.

$\mathrm{Na}$ verdade, se a Europa é percebida por muitos migrantes como terra de acolhimento, essa visão está longe de ser partilhada entre os próprios europeus. Assim, certos Estados europeus não hesitam em endurecer sua legislação a fim de tornar mais difícil o acesso ao seu território. Sua interpretação em relação à Convenção de Genebra sobre a proteção dos refugiados torna-se, por exemplo, mais restritiva. Ao mesmo tempo, os países-membros da União Europeia unificam sua política migratória (migração ilegal e asilo). Eles intervêm conjuntamente nas fronteiras do espaço Schengen e as tornam cada dia mais difíceis de serem cruzadas para certas categorias de populações. Isso se evidencia há alguns anos por uma baixa significativa do número de requerentes de asilo e de refugiados. A União Europeia também 
associa os países vizinhos à sua política de fechamento, estabelecendo com eles os planos operacionais de ação, a fim de lutar contra a imigração clandestina.

Assim, o processo de fechamento das fronteiras exteriores se reforça desde os anos 2000. Na verdade, as políticas de cooperação são implementadas no âmbito não apenas entre Estadosmembros da União Europeia, como também entre países-membros e países vizinhos. O Conselho Europeu adotou, em junho de 2002, um plano para a gestão integrada de fronteiras exteriores dos Estados-membros da União. Ele reúne os trabalhos da Comunidade Europeia e avaliza a ideia da criação de um corpo europeu de guardas de fronteira. Em 2005, foi criado o FRONTEX, a agência europeia para a gestão da cooperação operacional das fronteiras exteriores dos Estados-membros da União Europeia, criada pelo regulamento (CE), n²007/2004 do Conselho (de 26 de outubro de 2004, JO L 349, de 25.11.2004). Desde 2004, o processo de cooperação vem sendo estendido aos países não-membros da União Europeia seguindo a implementação da política europeia de vizinhança, associando cinco países a Leste e nove ao Sul. Em suma, trata-se de uma zona-tampão que será regulada às margens da Europa para filtrar os migrantes em trânsito.

\subsection{AS CONSEQUÊNCIAS DESSA POLÍTICA}

Se essa política de fechamento impõe aos migrantes uma verdadeira vida de dificuldades, ela não chega evidentemente a travar a imigração, pois esse objetivo seria por definição irrealizável. Ao contrário, essas medidas custosas se mostram seletivas, alimentando os atravessadores de migrantes e pisando sobre os direitos do homem, valor europeu por excelência, o que se traduz por uma forte mortalidade nas fronteiras externas da Europa.

O sistema de vistos e de vigilância das fronteiras instaurou uma discriminação entre os mais ricos e os outros. Ele instaurou também uma seleção entre os mais fortes e os mais fracos, sendo que são as cabeças pensantes dos países "emissores" que são autorizadas a emigrar. É necessário perceber que certas ideias concebidas são falsas: não são os mais pobres que partem, mas aqueles que dispõem de uma rede, família instalada no estrangeiro, de uma soma de dinheiro bastante importante quando o cruzamento é impossível pela via legal. Mas, antes de tudo, esses sistemas instalam, por sua vez, o reino da corrupção em todas as escalas, tanto na Europa como nos países de origem. Os primeiros a pagar são os migrantes. Como as fronteiras são fechadas e vigiadas, hoje os migrantes não têm outra escolha a não ser pagar pelos serviços de atravessadores. Esses se adaptam à situação: quanto maior a vigilância, 
mais eles recorrem a meios sofisticados; quanto mais a migração é criminalizada, mais ela é retomada pelas organizações "criminosas", maiores são os riscos e mais altos são os preços.

Figura 09. Mortos nas fronteiras da Europa

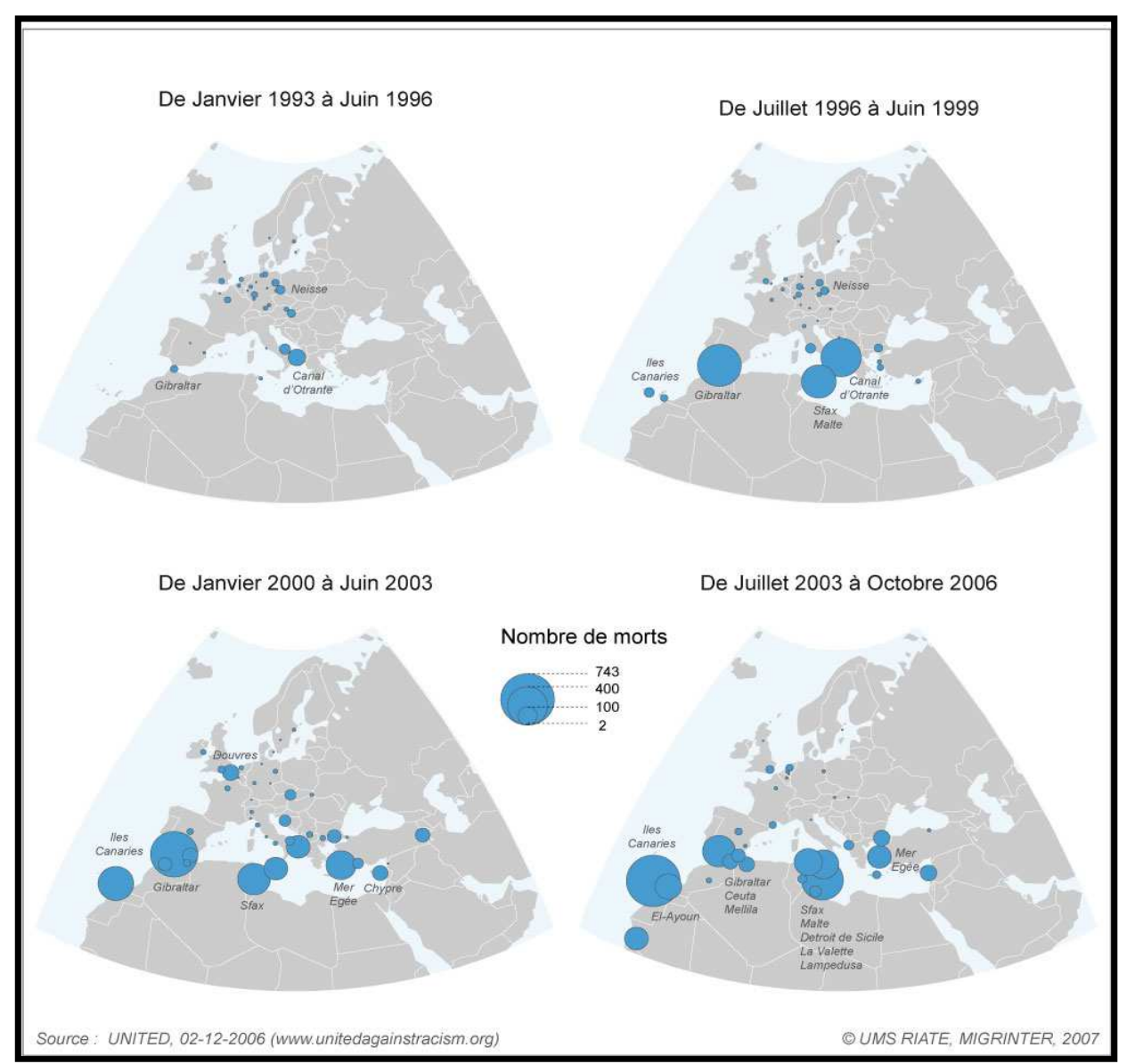

Fonte: Didelon C. Grasland C. Richard Y, Atlas de l'Europe dans le monde.

Além de seu custo financeiro, essas políticas de fechamento de fronteiras têm um custo humano muito grande: mais de 2 milhões de migrantes foram mortos desde 1993, a maior parte nas fronteiras. Mas há também os que sucumbem nas expulsões, os mortos por falta de assistência médica, como o caso do nigeriano em Liège, em 1998; os mortos sob custódia, como os velhos tunisianos em Marselha. Os centros de detenção são os universos fechados onde a dominação do ser humano é colocada em prática legalmente. A máquina de expulsar gera sua cota de violência e de medo ao ritmo das banalidades cotidianas. Alguns "erros" são por vezes denunciados, para melhor estabelecer o sistema de impunidade. As violências, o racismo, as violações de direitos do homem são inerentes à política de fechamento das fronteiras. Assim, em oposição aos discursos atenuados e combinados sobre 
os direitos do homem, a Figura 09 aponta o destino de inúmeros migrantes que tentam a passagem das fronteiras Schengen. O Mare Nostrum é cada vez mais vigiado, e o reforço dos controles migratórios conduz à reconstrução de verdadeiros dispositivos militares no nível das fronteiras. O aumento do número de afogamentos em locais distantes dos estreitos de Gibraltar, da Sicília e de Otrante aponta a utilização de novas rotas migratórias que vêm a ser mais longas e mais arriscadas. Desde 2005, alguns percursos marítimos vão de Dakar em direção às Ilhas Canárias ou da Líbia em direção à Itália. Assim, os dispositivos de controles implantados nas fronteiras exteriores tornam as margens europeias cada vez mais mortais. Essa escolha política consolida a representação de uma Europa-fortaleza, onde os direitos do homem são, a cada dia, achincalhados em suas portas. Esse estado, de fato, aponta a contradição entre a política e os valores afirmados como sendo constitutivos da identidade europeia.

\section{CONSTRUÇÃO DO TERRITÓRIO EUROPEU E A QUESTÃO DAS FRONTEIRAS INTERNAS}

\subsection{OS ACORDOS SCHENGEN}

Desde 1990, fenômenos múltiplos atravessam a Europa. Entre esses últimos, observamos dois processos sincrônicos e contraditórios. De uma parte, a edificação do Mercado Comum que deu origem à Comunidade Europeia e foi traduzido por um relativo enfraquecimento das fronteiras internas. Esse processo é acelerado e ampliado pelo aprofundamento da União Europeia e uma desfuncionalização das fronteiras entre os paísesmembros. Assim, as regiões de fronteira como a Alsácia para a França se encontram no coração de um espaço transfronteiriço, enquanto Estrasburgo se torna uma capital europeia. De outra parte, a Europa se dota de uma política de imigração comum: os acordos de Schengen (Figura 10).

O acordo (os princípios, em 1985), depois a convenção (as modalidades de aplicação, adotadas em 1991) de Schengen (cidade de Luxemburgo) são considerados como "laboratório" da livre circulação de pessoas. Os acordos de Schengen são fruto de uma iniciativa franco-alemã. Tratava-se, depois da Europa econômica, de projetar a construção de uma Europa de cidadãos, na qual a liberdade de circulação seria garantida pela supressão de fronteiras físicas. O objetivo dos acordos é a livre circulação de pessoas no conjunto de territórios dos Estados signatários. Essa liberdade deve ser possível graças à supressão dos 
controles nas fronteiras interiores. O princípio de livre circulação no interior da U.E. já estava presente no Tratado de Roma, mas divergências sobre as pessoas que teriam essa liberdade de circulação (todas as pessoas ou somente as europeias) atrasaram, até os acordos de Schengen, o avanço das negociações. Quando da assinatura do acordo (em 1985), somente 5 países estavam incluídos: Alemanha, França, Bélgica, Países Baixos e Luxemburgo. No momento

\section{Figura 10. O espaço Schengen}

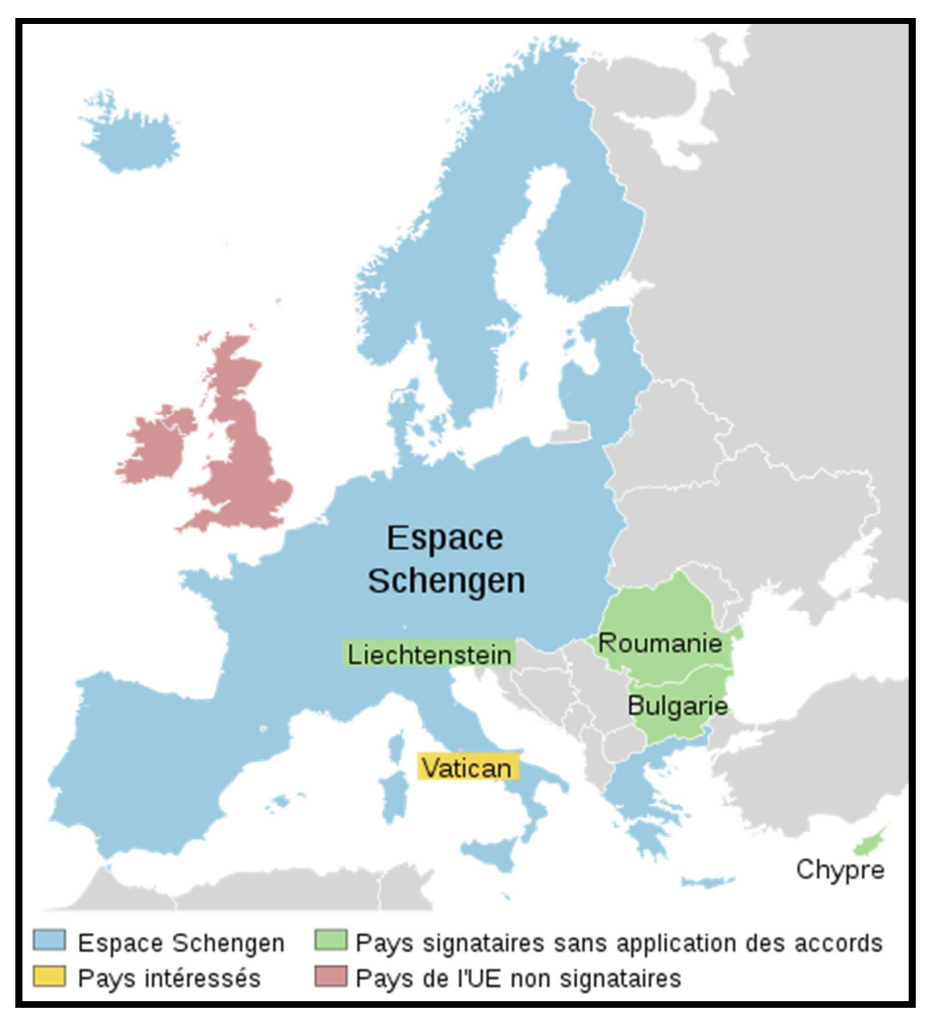

Fonte: Wikipedia.fr

da implementação (26 de março de 1995), dois novos países se juntaram ao processo: Espanha e Portugal. Atualmente, quase todos os países da União Europeia são signatários dos acordos de Schengen, assim como os países não-membros. Excetuando a Grã-Bretanha e a Irlanda, o conjunto de países assinou progressivamente a convenção da aplicação do acordo Schengen, mesmo se eles aplicam ainda, por vezes, o controle nas fronteiras nacionais em níveis diversos.

As oposições à implantação dos acordos de Schengen têm permanecido vivas. Alguns estimam que esse acordo poderia desembocar em uma "Europa- coador". O fato de o controle da entrada no país não se estabelecer mais na fronteira nacional, mas longe dela, faz crer a muitos a possibilidade de ver os estrangeiros ou a droga entrar mais facilmente. Aliás, a 
constituição do Espaço Schengen provoca o abandono de uma soberania nacional primordial: o controle das fronteiras. As fronteiras nacionais são preteridas em relação ao limite dos países signatários, o que não permite ao Estado controlá-las como ele pretende. O símbolo da fronteira é abalado: com a supressão do controle da fronteira, alguns têm a impressão que é o Estado que perde sua legitimidade e assim perde seu poder.

Com o recuo, não é contestável que os acordos de Schengen se deparem com dificuldades de aplicação, principalmente devido à falta de harmonização no que concerne a políticas migratórias de países-membros, o que conduz à situação de fechamento das fronteiras exteriores que descrevemos anteriormente. Todavia, o enfraquecimento das fronteiras internas da União Europeia tem igualmente impactos muito importantes sobre o território europeu, principalmente no que se refere aos territórios transfronteiriços.

\subsection{AS CONSEQUENCIAS TERRITORIAIS E O ENFRAQUECIMENTO DAS FRONTEIRAS INTERNAS DA UNIÃO EUROPEIA}

A construção do território europeu por meio da política regional é igualmente expressa através dos programas de cooperação transfronteiriça, sendo o programa INTERREG primordial no âmbito da política regional. Seu objetivo é o de costurar os espaços que estavam anteriormente separados por uma fronteira, a fim de fazer emergir novos espaços transfronteiriços e, se possível, um novo "rincão de vida" ${ }^{10}$ para as populações, ou mesmo novos territórios. Assim, desde o período 1994-1999, um componente transnacional foi adicionado aos programas de cooperação lançados pela Comissão Europeia e que permite desenvolver as trocas ao redor de projetos-alvo. Os mapas possibilitam visualizar a extensão territorial de cada área de cooperação no interior da U.E. e com os países vizinhos (Figura 11). A maior parte das regiões europeias pertence a dois ou três espaços de cooperação transnacional.

Assim, 13 zonas de cooperação foram definidas em acordo entre a Comissão e os Estados-membros para o período 2007-2013. Elas abrangem espaços variados que vão das zonas montanhosas do espaço alpino às ilhas do Caribe. A fim de aumentar a cooperação de uma parte e de outra das fronteiras externas da U.E., esses programas associam alguns países vizinhos, como no espaço do Mar Báltico, por exemplo. As ações são co-financiadas pelo

\footnotetext{
${ }^{10}$ Bassin de vie no original (NT).
} 
Figura 11. Espaços de cooperação transnacional

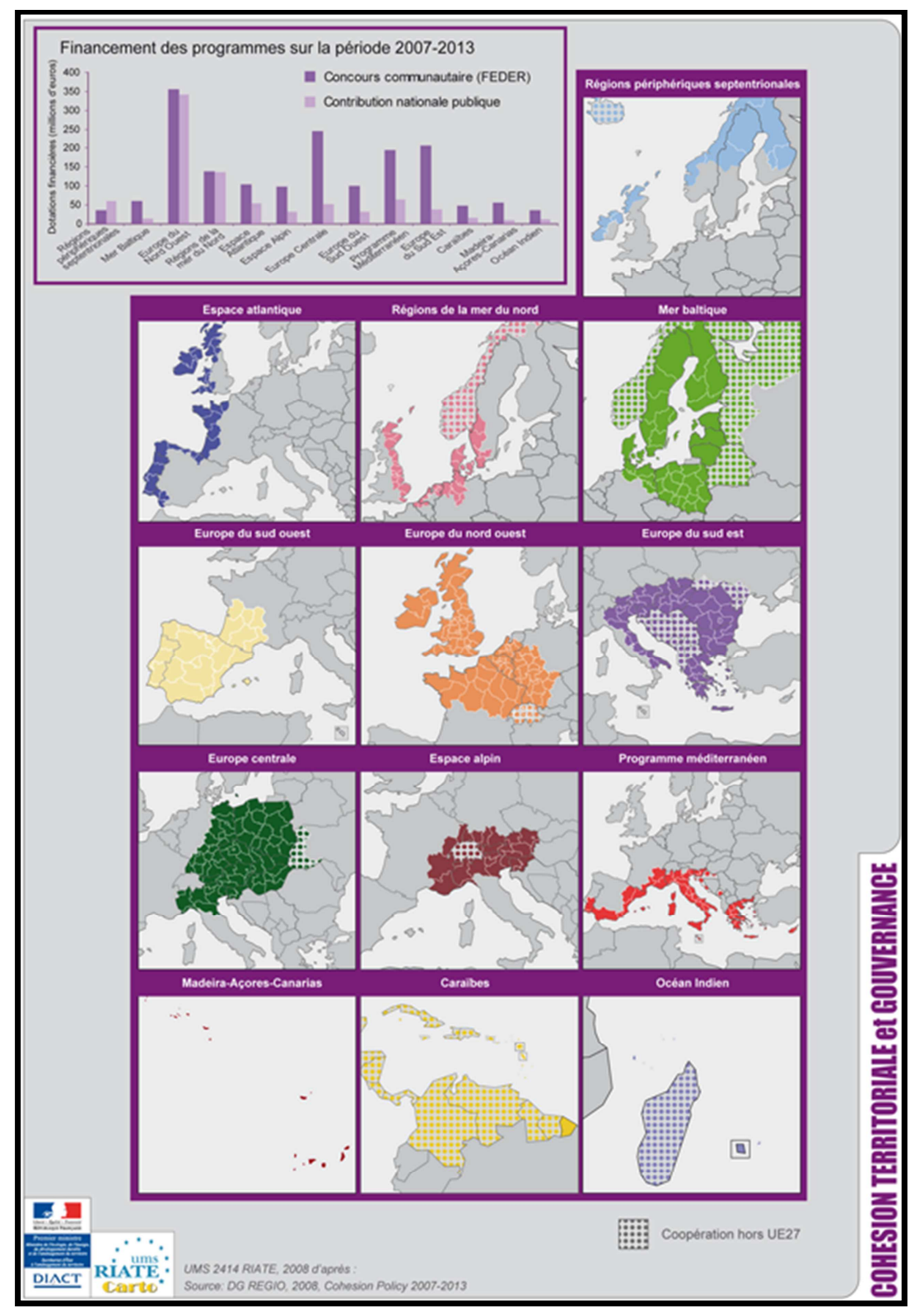

Fonte: UMS RIATE

Fundo de Desenvolvimento Regional (FEDER), pelo instrumento europeu de vizinhança e a parceria com os países vizinhos (IEVP), e os Estados-membros, que apoiam os projetos em domínios diversos. As prioridades são a inovação, em particular a implantação de redes de universidades, instituições de pesquisa e PME (pequenas e médias empresas); o meio ambiente, em especial os recursos de água, rios, lagos, mares; a acessibilidade, incluindo as telecomunicações, em particular no que concerne ao acabamento das ligações pendentes; o desenvolvimento urbano durável, em particular numa perspectiva policêntrica. 
A cooperação transfronteiriça (Figura 12) é desenvolvida em nível pan-europeu pelos 27 países da U.E., além da Noruega e Suíça. Em termos de coesão territorial, o objetivo é principalmente o de construir as redes para desenvolver e facilitar a troca e a transferência de experiências das regiões mais favorecidas em benefício das mais pobres.

Figura 12. Programas transfronteiriços 2007-2013

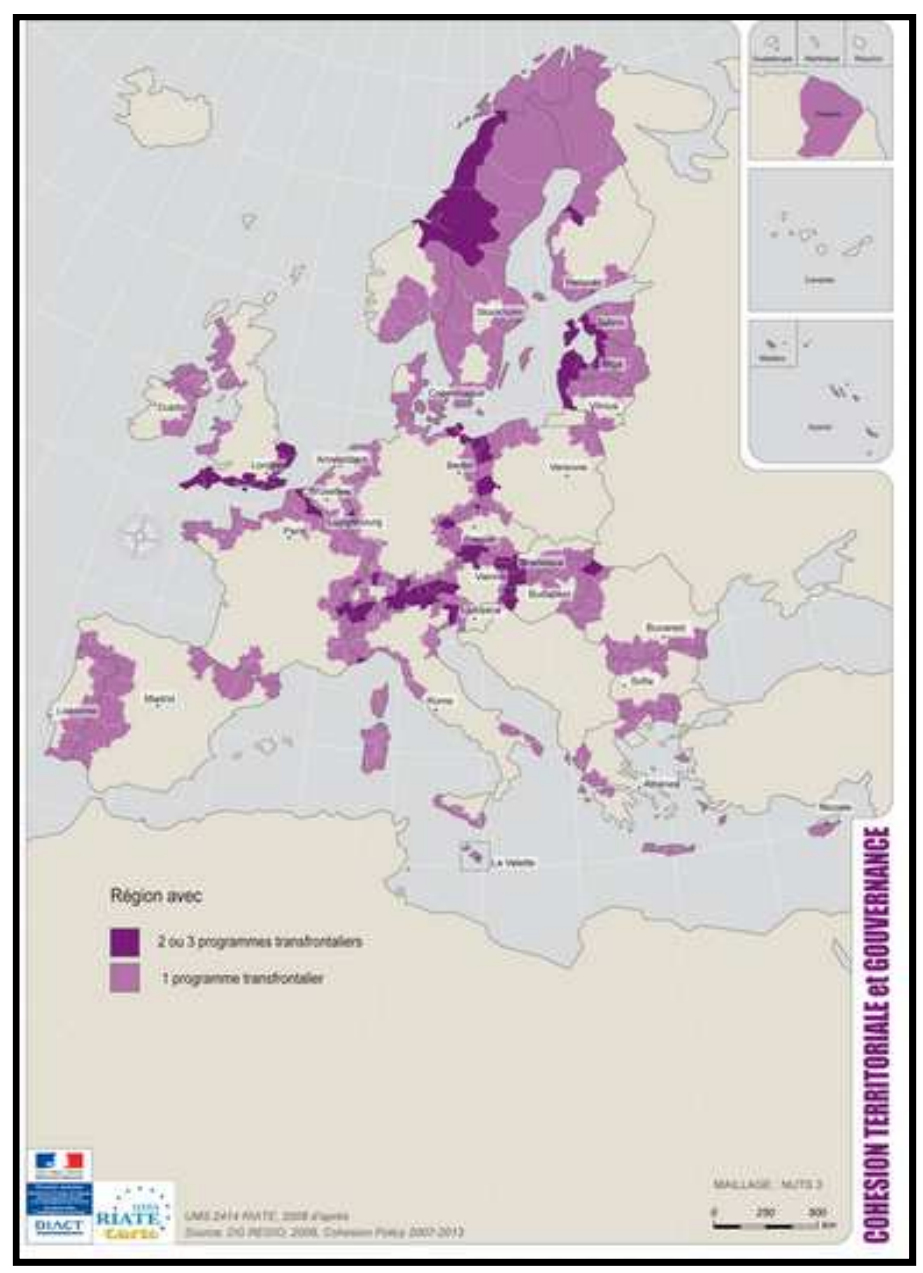

Fonte: UMS RIATE

A análise do território institucional localizado na fronteira franco-alemã, o eurodistrito Estrasburgo-Ortenau, ilustra perfeitamente o efeito do enfraquecimento relativo das fronteiras internas da U.E. e a emergência de territórios transfronteiriços.

Antes da instauração dos acordos de Schengen, as populações não podiam circular totalmente livres de uma parte a outra da fronteira. $\mathrm{O}$ enfraquecimento relativo das fronteiras internas da U.E. se traduz pelo enfraquecimento da função de controle da fronteira, que do "estatuto de corte passa ao de costura" (LEOUP F. e MOYART, L., 2006). Na verdade, nosso 
estudo revelou que os habitantes dessa aglomeração atravessam regularmente a fronteira: no espaço de três meses, $95 \%$ dos entrevistados ${ }^{11}$ estiveram do outro lado da fronteira. Os principais motivos evocados para esse fluxo são bastantes similares, qualquer que seja o perfil das pessoas entrevistadas (nacionalidade ou idade): a primeira causa citada é de ordem econômica, porque 66,9\% dos entrevistados citaram as compras ou o shopping. Essa cifra está de acordo com a que foi dada pela CCI de Estrasburgo, a qual estima que $40 \%$ da clientela de Kehl é alsaciana. Na verdade, a fronteira induz um diferencial econômico explorado pelas populações transfronteiriças. Além disso, alguns organismos publicam estudos comparativos sobre os preços praticados de uma parte a outra da fronteira. Além dos motivos econômicos, as outras causas evocadas são, por ordem de importância de respostas, o lazer, as visitas a amigos ou à família, os passeios, o turismo. Os deslocamentos profissionais (4\% dos entrevistados citaram essa causa) seguem relativamente fracos, confirmando as observações de G. Traband (2008), que nos informa que "Estrasburgo não gerou uma bacia de emprego transfronteiriça".

As práticas transfronteiriças não são cotidianas, visto que só 21,5\% dos entrevistados passam ao menos uma vez por semana do outro lado da fronteira, enquanto que mais metade das pessoas entrevistadas vai uma vez por mês ou menos até o outro lado da fronteira. Assim, mesmo se a fronteira franco-alemã tenha visto enfraquecer sua função de controle, ela ainda continua presente. Na verdade, a fronteira possui outras funções, que permanecem ainda bem presentes hoje e que podem explicar, em parte, esses resultados: as funções imaginária e simbólica, a função legislativa e a função fiscal. A função imaginária e simbólica da fronteira remete ao campo do ideal, das percepções que influem sobre suas mobilidades e sobre a construção de novos territórios. De fato, se a fronteira não é materialmente presente sobre o território, ela continua presente na mentalidade das pessoas. Na verdade, $41 \%$ da amostra estudada declararam perceber a fronteira e $60 \%$ dos entrevistados declararam perceber uma descontinuidade de uma parte a outra da fronteira.

Essa fronteira mental pode se explicar pela história desses dois países. A França e a Alemanha se enfrentaram, realmente, ao longo de inúmeras guerras. Contudo, há que se relativizar essa questão, porque $81 \%$ dos entrevistados pensam que as guerras não constituem mais, no momento atual, um entrave para a constituição de um território transfronteiriço praticado por seus habitantes. Além da história, as diferenças culturais e principalmente

\footnotetext{
${ }^{11}$ A pesquisa foi realizada com 79 habitantes de Kehl e 179 de Estrasburgo.
} 
linguísticas podem explicar esses resultados. $\mathrm{Na}$ verdade, apenas 30\% dos estrasburguenses entrevistados e $25 \%$ dos habitantes de Kehl afirmaram falar a língua do vizinho.

Se a função imaginária e simbólica da fronteira influencia as práticas cotidianas, as funções legislativas e fiscais influenciam mais particularmente as mobilidades residenciais. Há dez anos, eram principalmente os alemães que vinham se instalar na França. Atualmente, as tendências se inverteram. Estimamos que hoje, em Kehl, sobre uma população total de 35 mil habitantes, mais de 1000 sejam franceses. Além disso, estimamos que um novo francês se instala em Kehl a cada dia. Essa tendência se explica pelo custo dos imóveis, pelo acolhimento reservado aos novos habitantes, assim como pela qualidade do nível de vida. Gérard Traband nos informa que um cinturão residencial estrasburguense está se formando na Alemanha. Ela inclui Kehl e suas comunas anexas de Leutesheim a Goldscheuer, passando por Kork (TRABAND, G., 2008). Contudo, nem todos os franceses podem se aproveitar dessa renda diferencial em razão do custo dos impostos na Alemanha. Assim, só os franceses que podem continuar a pagar seus impostos na França estão interessados em se instalar na Alemanha. Essas mobilidades residenciais são bastante complexas porque as leis não são as mesmas de uma parte e de outra da fronteira. Os regramentos administrativos são igualmente complexos. A fim de facilitar a vida cotidiana dos habitantes desse território transfronteiriço, os representantes cooperam, o que não é simples, em razão das diferenças legislativas de uma parte a outra da fronteira, ainda que as ferramentas existam.

Os desafios e os objetivos dessas práticas de cooperação transfronteiriça são múltiplos. Primeiro, convém fazer emergir um verdadeiro território trasnfronteiriço dispondo de equipamentos e de infraestruturas transfronteiriças, como, por exemplo, uma piscina, uma sala de ginástica ou ainda um bonde. Essas políticas têm igualmente permitido a construção do jardim de duas margens, jardim transfronteiriço, possibilitando encarnar essa cooperação e simbolizá-la. Além da criação de infraestrutura transfronteiriça, as políticas de cooperação têm também por finalidade facilitar a vida dos habitantes transfronteiriços, incluindo a simplificação das etapas administrativas ou ainda a organização das cooperações transfronteiriças. Desse modo, vemos o enfraquecimento da função de barreira das fronteiras internas da U.E., o que favorece a emergência de um território transfonteiriço institucionalizado sobre o plano político, representado e praticado pelos seus habitantes.

Portanto, a fábrica de novos territórios é relativamente difícil de implementar, e isso por diferentes razões. Primeiramente, há descontinuidades herdadas e sustentadas pelas políticas nacionais. Elas têm frequentemente induzido as fronteiras mentais particularmente 
fortes, especialmente quando a história entre dois países é marcada por enfrentamentos repetidos e violentos. Assim, a fronteira entre a Alemanha e os territórios franceses de Alsácia-Mosela permanece uma realidade bem marcada nos espíritos das populações fronteiriças francesas, devido aos três conflitos ainda recentes com a Alemanha e, sobretudo, à anexação desses territórios franceses ao império alemão entre 1871 e 1918 (Figura 13).

Figura 13. Representação da anexação da Alsácia-Lorena

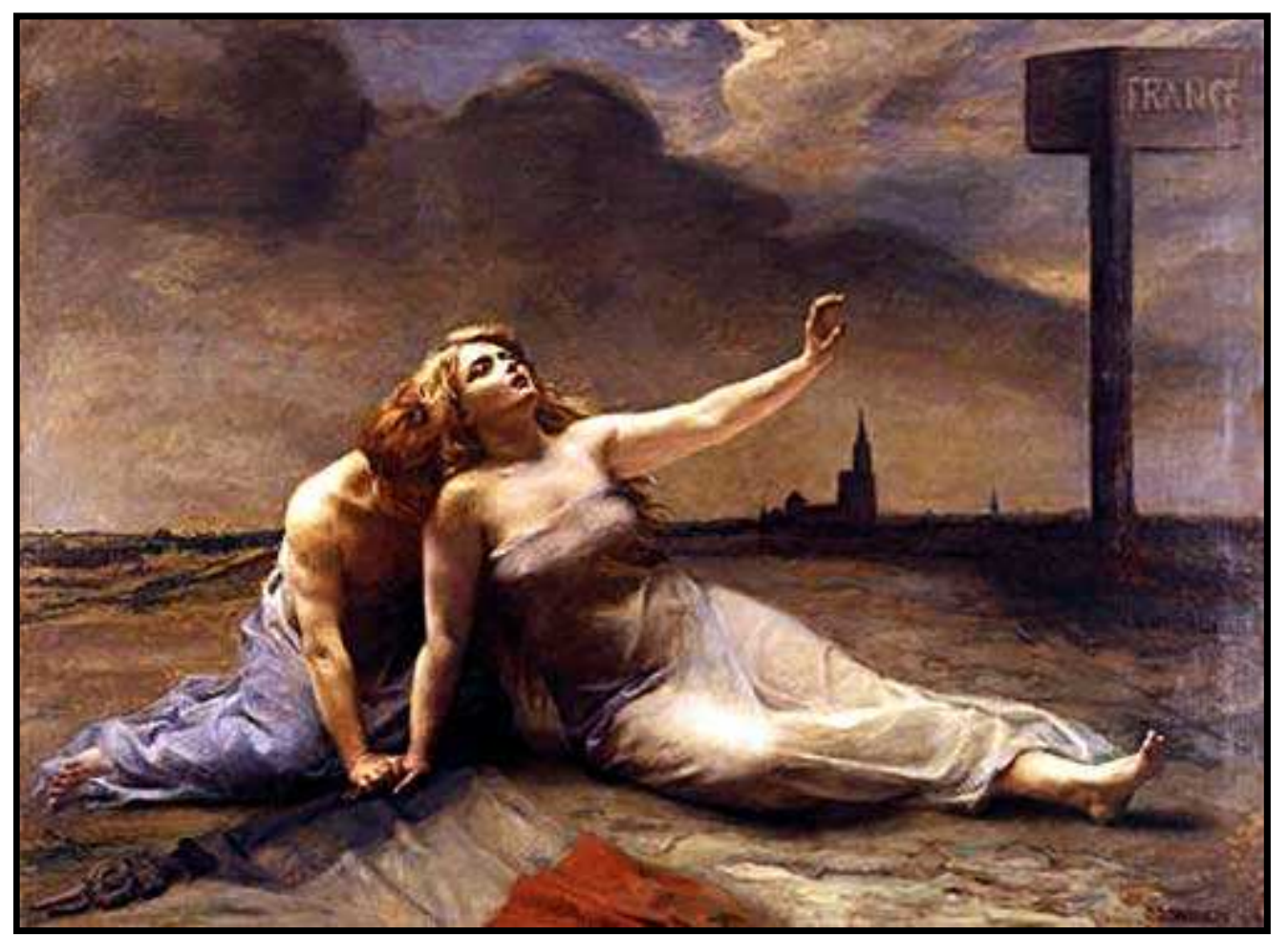

Fonte: http://www.lettresvolees.fr/degaulle/alsace.html. Jean-Joseph Weerts - France ou L'Alsace et la Lorraine désespérées (1906).

Dessa maneira, mesmo no interior da União Europeia subsistem conflitos territoriais que tornam por vezes difícil a criação de território transfronteiriço. É o caso do território de Gibraltar, sobre o qual subsiste um desacordo profundo entre a Grã-Bretanha e a Espanha. Nesse desacordo territorial, um conflito diz respeito à disputa sobre o aeroporto de Gibraltar e sua utilização. Deve-se lembrar ainda que a Grã-Bretanha não pertence ao espaço Schengen, ao contrário da Espanha. A Espanha desejaria que os passageiros espanhóis, ao desembarcar em Gibraltar, não precisassem passar pelos controladores britânicos e que os voos vindos da Espanha passassem a ser considerados voos domésticos. Mas, para a Grã-Bretanha, isso é uma redução inaceitável da soberania britânica sobre o rochedo. Em 1987, foi elaborado um 
acordo sobre a utilização conjunta pela Espanha e Gibraltar do aeroporto do rochedo, com a construção prevista de um segundo terminal, dando acesso direto ao território espanhol. Mas esse acordo provocou um clamor em Gibraltar, onde muitos enxergaram um primeiro passo na direção da anexação à Espanha. Desde então, a Espanha manobra a fim de excluir o aeroporto de Gibraltar da política europeia de desregulação, o que impede a implementação

Figura 14. A questão do aeroporto de Gibraltar

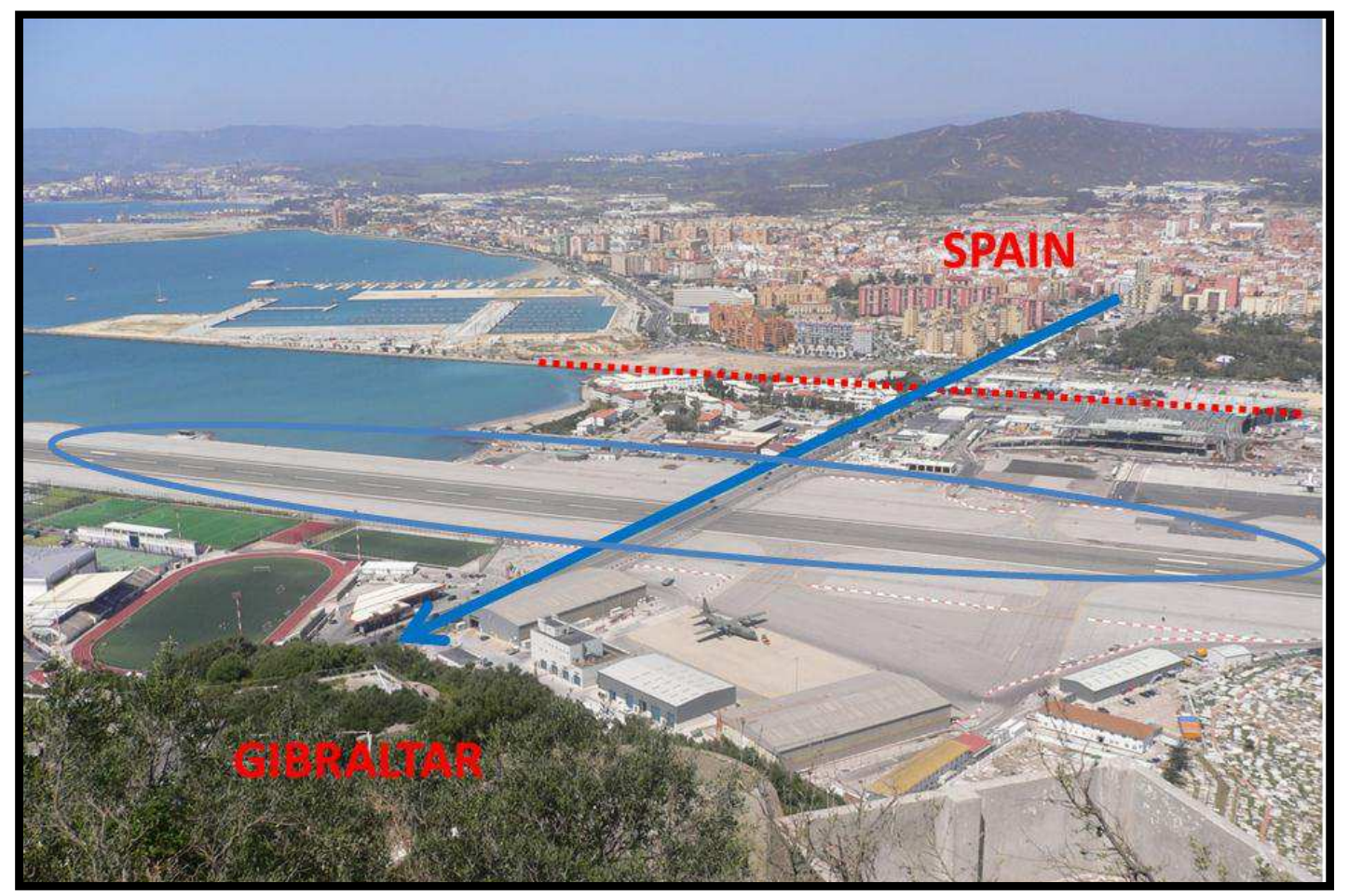

Fonte: Didelon C., 2010.

de linhas diretas com o resto da Europa. Além disso, os voos deveriam contornar o espaço aéreo espanhol até os acordos de Córdoba (18 de setembro de 2006, entre Gibraltar, Espanha e Grã-Bretanha). Assim, apesar da imbricação dos territórios (Figura 14) (a única rota de acesso a Gibraltar atravessa o aeroporto) e da existência de práticas transfronteiriças cotidianas (muitos espanhóis trabalham em Gibraltar), a construção de um território transfronteiriço nessas condições permanece difícil. 


\section{CONCLUSÃO}

O tema das fronteiras da Europa é, assim, uma questão sensível e particularmente complexa, afetando a questão da soberania dos Estados que a constituem. No interior do território europeu, as fronteiras internas se enfraquecem e desaparecem pouco a pouco, mesmo se todos os Estados-membros não aderem ao mesmo pacote institucional. Tudo é implementado no âmbito da política regional, a fim de apagar o peso das antigas fronteiras e de reconstruir territórios em processos frequentemente artificiais e longe de preocupações das populações dos espaços transfronteiriços. Por outro lado, em total contradição com os valores que fundam a identidade da Europa e os princípios que são propagados internamente, as fronteiras exteriores à U.E. se endurecem para as populações que buscam migrar.

\section{REFERÊNCIAS}

BADE K.J., 2004, Legal and illegal immigration into Europe: experiences and challenges, European Review, Vol. 12, No. 3, 339-375.

DIDELON C. GRASLAND C., Richard Y, 2008, Atlas de l'Europe dans le monde. La documentation française.

DIDELON C. GRASLAND, 2005, Rapport afinal du projet ESPON 3.4.1. Europe in the world. www.espon.eu

DIDELON C., 2010, Une vision de l'Europe ; Le tracé de l'Europe des chercheurs impliqués dans ESPON. Les annales de géographie, $n^{\circ} 673$.

GRATALOUP C., 2009, l'invention des continents, Larousse.

JOUEN M., 2008, La cohésion territoriale, de la théorie à la pratique, policy paper, notre Europe $\mathrm{n}^{\circ} 35$.

LELOUP F., Moyart L., 2006, «La Région frontalière: vers quels nouveaux modes de développement et de gouvernance?» in A.-L. Amilhat-Szary, M.-C. Fourny, Après les frontières, avec les frontières, Bibl. des Territoires, éd. L'Aube (38-55).

LÉVY J., 1997, Europe, une géographie, Hachette education.

SMITH J., 2000, overview and introduction. In International affairs, 76, 3 (2000) pp 437-441.

SOLLOGOUB T., 2006, Quelle convergence au sein de l'Union européenne élargie : Les enjeux pour la Bulgarie et la Roumanie ? Fondation Robert Schuman, Question d'Europe n 41.

SZTOMPKA P., 2004, From East Europeans to Europeans: shifting collective identities and symbolic boundaries in the New Europe, European Review, Vol. 12, No. 4, 481-496 (2004).

TRABAND G., 2008, Effacer la frontière? - Soixante ans de coopération franco-allemande en Alsace du Nord, Les nuées bleues. 